\title{
EKSISTENSI PAGUYUBAN HINDU JAWI DI KOTA PALANGKA RAYA
}

\author{
Agung Adi \\ Institut Agama Hindu Negeri Tampung Penyang Palangka Raya \\ Agungadigen@gmail.com
}

\begin{abstract}
Riwayat Jurnal
Artikel diterima: 4 Maret 2018

Artikel direvisi: 15 Mei 2018

Artikel disetujui: 1 Juni 2018
\end{abstract}

Kata Kunci:

Eksistensi,

Hindu Jawa,

Paguyuban Hindu Jawi

\section{Abstrak}

Penelitian ini bertujuan mendeskripsikan komunitas Hindu Jawa di Kota Palangka Raya-Kalimantan Tengah. Komunitas Hindu Jawa di Kota Palangka Raya tergabung dalam sebuah kelompok paguyuban dengan nama Paguyuban Hindu Jawi (Pandu Jawi). Aspek yang dikaji terfokus pada eksistensi Paguyugan Hindu Jawi di Kota Palangka Raya. Jenis penelitian adalah kualitatif karena data yang dibutuhkan lebih bersifat data deskriptif berupa katakata tertulis, lisan dan perilaku orang-orang yang dapat diamati. Bentuknya adalah studi kasus. Pengumpulan data dilakukan dengan tiga cara, yaitu; observasi, wawancara mendalam, dan studi dokumen. Penentuan informan dilakukan dengan purposive sampling.

Hasil penelitian menyimpulkan eksistensi Paguyuban Hindu Jawi di Kota Palangka Raya ditopang oleh berbagai bentuk kegiatan yang dilakukan, baik secara eksternal dan internal. Kegiatan eksternal seperti; pelatihan fermentasi makanan ternak; gotong royong; memberikan pandehen dalam persembahyangan basarah. Sedangkan secara internal, kegiatan paguyuban diarahkan pada kegiatan arisan dan berbagai ritus slametan termasuk menyelenggarakan basarah. Aktivitas-aktivitas yang dilakukan oleh Paguyuban Hindu Jawi memiliki fungsi-fungsi tertentu yaitu sebagai penyangga sosial-budaya dan pemberdayaan ekonomi umat Hindu di Kota Palangka Raya.

\section{Keyword:}

\section{Abstract}

Existence

The aim of this study to describe the Javanese Hindu

Javanese Hinduism community in the City of Palangka Raya-Central Paguyuban Hindu Jawi Kalimantan. The Javanese Hindu community in the City of Palangka Raya is incorporated into a community group with the name of the Pagu yuban Hindu Jawi (Pandu Jawi). The aspects of studied were focused on the existence of the Paguyuban Hindu Jawi in the City of Palangka Raya. The 


\begin{tabular}{|l|l|}
\hline & $\begin{array}{l}\text { research is qualitative because of the data needed is more } \\
\text { descriptive data in the form of written words, oral and } \\
\text { behavior of people who can be observed. The form is a case } \\
\text { study. Data collection is done in three ways, namely; } \\
\text { Observation, in-depth interviews, and document studies. } \\
\text { Determination of informants is done by purposive sampling. } \\
\text { The results of the study showed that the existence of } \\
\text { the Pagu y ban Hindu Jawi in Palangka Raya City was } \\
\text { supported by various forms of activities carried out, both } \\
\text { externally and internally. External activities such as; training } \\
\text { on fermented livestock food; mutual cooperation; giving } \\
\text { pandehen in basarah worship. Whereas internally, the } \\
\text { community activities are directed at arisan activities and } \\
\text { various slametan rites including organizing basarah. } \\
\text { Activities carried out by the Pag u u b H Hindu Jawi have } \\
\text { certain functions, namely as a support for socio-culture } \\
\text { and economic empowerment of Hindus in the City of } \\
\text { Palangka Raya. }\end{array}$ \\
\hline
\end{tabular}

\section{Pendahuluan}

Agama Hindu menerima segala bentuk gambaran kebenaran dan Tuhan. Agama ini berpandangan bahwa secara universal hanya ada satu realitas sejati tetapi realitas itu tidak dapat dibatasi sebagai satu nama atau bentuk tertentu. Meski kebenaran hanya satu dan universal, tetapi ia tidak dapat dirumuskan secara eksklusif (terbatas), melainkan inklusif (terbuka terhadap berbagai penafsiran) (Takwin, 2009, p. 54). Bahkan Swami Siwananda berpendapat, orang lain akan merasa heran apabila ia mendengar tentang sekte-sekte dan keyakinan yang berbeda dalam Hindu; tetapi perbedaan-perbedaan itu sesungguhnya merupakan berbagai tipe pemikiran dan temperamen sehingga menjadi bermacam-macam keyakinan. Hal ini adalah wajar bahkan merupakan ajaran yang utama dari Hinduisme. Karena dalam Hindu tersedia tempat bagi semua tipe roh dari yang tertinggi sampai yang terendah, demi untuk pertumbuhan mereka" (Titib, 1998, p. 33).

Berbagai perbedaan sebagaimana diungkapkan oleh Swami Siwananda dapat pula dibuktikan dengan tidak ditemukannya praktek yang sama bahkan diseragamkan dalam ritusritus agama Hindu, terutama pada saat orang Hindu melakukan hubungan intens dengan Tuhannya. Artinya orang Hindu dapat memaknai eksistensi Tuhannya kemudian melakukan hubungan pemujaan dengan berbagai jalan atau cara yang tepat sesuai dengan keyakinan dan jangkauan pengetahuannya. Oleh sebab itu, Radhakrisnan mengamati, “ajaran Hindu lebih cocok sebagai budaya dibandingkan sebagai agama”. Sejalan dengan Venkateswaran yang 
mengemukakan, “ajaran Hindu tidak hanya sekadar agama, karena mencakup seluruh aspek peradaban serta cara hidup yang telah berakar sebelum 3000 SM. Sebagai jalan hidup, ajaran Hindu terdapat dalam berbagai bentuk. Misalnya, adanya bermacam-macam ritual dan upacara (Samovar, Larry A. Porter, Ricard E. McDaniel, Edwin R. , 2010, pp. 163-164). Menyoal berbagai ritual dan upacara, dalam implementasinya, agama Hindu berkelindan dengan budaya lokal yang dilauinya, semisal Hindu di Indonesia.

Hindu di Indonesia dalam perkembangannya senafas dengan kebudayaan yang dilalui, dalam wujud inilah yang kemudian melahirkan peristilahan ragam dalam sebutan Hindu, seperti; Hindu Bali. Hindu Bali maksudnya adalah umat Hindu yang menggunakan budaya Bali dalam berbagai aktivitas keagamaannya. Antara agama Hindu dan budaya Bali terkadang sulit untuk dipisahkan karena keduanya adalah dua fenomena dalam satu kenyataan (Geria, 2009). Demikian halnya dengan Hindu Jawa, Hindu Toraja, Hindu Bugis, Hindu Ambon, Hindu Karo, Hindu Tengger, dan Hindu Kaharingan.

Pluralitas budaya sebagai identitas dalam agama Hindu dapat dilihat dari keberadaan Hindu di Kalimantan Tengah. Kalimantan Tengah merupakan salah satu daerah yang memiliki jumlah pemeluk agama Hindu cukup besar. Data Kementerian Agama Provinsi Kalimantan Tengah mencatat jumlah pemeluk Hindu 218.890 jiwa dengan mayoritas pemeluknya adalah suku Dayak, kemudian suku Bali dan Jawa. Sedangkan di Kota Palangka Raya jumlah umat Hindu tercatat 7.957 Jiwa (Hartati, 2015). Latar belakang perbedaan suku masyarakat Hindu di Kalimantan Tengah melahirkan keniscayaan perbedaan budaya dalam aktivitas keagamaan.

Penelitian ini berupaya menelusuri salah satu identitas sosial-budaya sebagai varian budaya dalam agama Hindu di Kota Palangka Raya, yaitu identitas Hindu Jawa. Hindu Jawa pada dasarnya sebutan untuk mengidentifikasi umat Hindu yang berasal dari pulau Jawa yang dalam aktivitas keagamaanya mempergunakan tradisi dan budaya Jawa. Kebudayaan Jawa dikenal memiliki kelenturan dalam proses dialog dengan seluruh kebudayaan yang ada dari luar dirinya. Dalam setiap proses dialog, kebudayaan Jawa senantiasa dapat menemukan kembali jati dirinya. Yang terjadi adalah akulturasi dan pergumulan, yang kemudian menghasilkan sosok budaya baru. Proses dialog inilah yang disebut dengan transformasi perubahan bentuk dan watak masyarakat (Efendi, 1997, p. 43). Selain itu, mistik (spiritual) orang Jawa banyak yang memiliki keserupaan bahkan kesamaan dengan agama Hindu, misalnya tentang hakekat Tuhan menurut orang Jawa, Hubungan Tuhan dengan ciptaanya, ajaran semedi, ajaran moral, hukum karma (Suripto, 2006, pp. 16-17). Ajaran-ajaran ini acap disebut dengan Kejawen, oleh sebab itu Hindu Jawa adalah umat Hindu yang aktivitas 
keagamannya dilaksanakan berdasarkan ajaran Kejawen yang tidak jauh berbeda dengan ajaran Hindu lainnya (Sutrisno, 2009, p. 196).

Hindu Jawa di Kota Palangka Raya tergabung dalam komunitas Paguyuban Hindu Jawi (Pandu Jawi). Paguyuban ini memiliki aktivitas pertemuan rutin sekali dalam sebulan dengan para anggotanya, kegiatan sosial dan ritus lingkaran hidup acap diselenggarakan oleh Pandu Jawi. Hal ini menunjukkan bahwa mereka memiliki eksistensi di tengah pluralnya masyarakat Hindu di Kota Palangka Raya.

\section{Metode Penelitian}

Penelitian ini adalah penelitian kualitatif karena data yang dibutuhkan lebih bersifat data deskriptif berupa kata-kata tertulis, lisan dan perilaku orang-orang yang dapat diamati. Bentuknya adalah studi kasus, dengan fokus penelitian mengarah pada Paguyuban Hindu Jawi (Pandu Jawi) di Kota Palangka Raya. Sehingga pokok elaborasi adalah hal-hal yang berhubungan dengan latar belakang keberadaan Paguyuban Hindu Jawi, sturktur organisasi dan pengelolaanya, cara-cara memepertahankan agama Hindu melalui aktivitas keagamaan dengan balutan budaya Jawa.

Pengumpulan data dilakukan dengan tiga cara, yaitu; observasi, wawancara mendalam, dan studi dokumen. Penentuan informan dilakukan dengan purposive sampling, pemilihan penentuan informan dengan purposive sampling untuk menghindari bias makna dan memperolah informasi utuh dalam berbagai aktivitas Paguyuban Hindu Jawi. Berdasarkan pertimbangan tersebut, orang-orang yang dipilih sebagai informan adalah memiliki pengetahuan agama Hindu dan budaya Jawa dengan baik dan memiliki pengaruh signifikan terhadap eksistensi Paguyuban.

Analisis data dalam penelitian ini dilakukan melalui tiga jalur kegiatan yang merupakan satu kesatuan yaitu (1) reduksi data, (2) penyajian data, (3) penarikan kesimpulan atau verifikasi. Reduksi data adalah suatu proses memilah, pemusatan perhatian pada penyederhanaan, pengabstrakan, dan transformasi data mentah atau data kasar yang muncul dari catatan-catatan tertulis dan hasil rekaman wawancara yang diperoleh dari lapangan. Penyajian data dimaksudkan untuk menemukan pola-pola yang bermakna serta memberikan kemungkinan adanya penarikan kesimpulan dan pengambilan tindakan. Penyajian data dalam penelitian ini merupakan proses penyajian sekumpulan informasi yang kompleks ke dalam kesatuan bentuk yang sederhana dan selektif sehingga mudah dipahami maknanya. Data yang diperoleh selama penelitian dipaparkan, kemudian dicari tema-tema yang terkandung di dalamnya sehingga jelas maknanya. Selanjutnya, penarikan kesimpulan dilakukan setelah 
melalui proses analisis data, baik analisis selama pengumpulan data maupun analisis setelah pengumpulan data.

\section{Hasil Penelitian}

\section{Deskripsi Kota Palangka Raya}

Penduduk Kota Palangka Raya terdiri dari penduduk asli dan penduduk pendatang. Penduduk asli yang dominan adalah Dayak Ngaju, kemudian Dayak Maanyan, Dayak Lawangan, Dayak Siang Murung, Dayak Dusun, Dayak Bawo, Dayak Taboyan, Dayak Bakumpai, Dayak Katingan, Dayak Kotawaringin, Dayak Ot Danum, Dayak Sampit, Dayak Lamandau, Dayak Bulik, Dayak Menthobi dan Dayak Seruyan yang sebenarnya masih masih termasuk dalam rumpun suku Dayak Ngaju (Danandjaja, 1975, p. 120) (Armadiansyah, Eksistensi Damang Sebagai Hakim Perdamaian Adat Pada Masyarakat Suku Dayak di Palangka Raya, 2011, p. 40). Dalam komunikasi sehari-hari mereka menggunakan bahasa Dayak Ngaju (Biaju) sebagai bahasa persatuan, sedangkan bagi penduduk pendatang pada umumnya menggunakan bahasa Indonesia dan bahasa Banjar. Secara umum penduduk Kota Palangka Raya didominasi oleh Pegawai Negeri Sipil (PNS), pelajar dan mahasiswa. Sehingga Kota Palangka Raya acap dijuluki sebagai kota pegawai dan kota pelajar.

Selain penduduk asli Suku Dayak, terdapat suku pendatang yang dominan yaitu suku Banjar atau yang lebih dikenal dengan orang Melayu Banjar yang berasal dari Kalimantan Selatan. Jumlah Melayu Banjar cukup dominan diantara pendatang lainnya kebanyakan mereka menjadi pedagang dan biro jasa angkutan kota (Armadiansyah, Eksistensi Damang Sebagai Hakim Perdamaian Adat Pada Masyarakat Suku Dayak di Palangka Raya, 2011). Selain pendatang dari Melayu Banjar, terdapat pendatang lainnya yaitu suku Batak, Sunda, Madura, Bali, Jawa dan banyak lagi suku-suku yang menempati kota cantik ini. Konsekuensi dari keberagaman suku itu melahirkan budaya yang beraneka ragam, tampilan keberagaman budaya di Kota Palangka Raya acap menjadi pertunjukan tahunan melalui kegiatan pawai budaya yang diprakarsai pemerintah daerah melalui dinas Pariwisata dan Budaya. Melihat latarbelakang penduduk Kota Palangka Raya berdasarkan suku bangsanya yang sangat plural, banyak yang menggambarkan kota ini adalah miniatur Indonesia. Ditinjau dari prosentase suku bangsa yang ada di Kota Palangka Raya yaitu, suku Dayak (46,62\%), Jawa $(21,67 \%)$ dan Banjar (21,03\%), Melayu (3,96\%), Madura (1,93\%), Sunda (1,29\%), Bugis $(0,77 \%)$, Batak $(0,56 \%)$, Flores $(0,38 \%)$, Bali $(0,33 \%)$ dan suku lainnya (BPS, 2017).

Kehidupan beragama dan kegiatan keagamaan di Kota Palangka Raya mendapat perhatian serius dari pemerintah provinsi Kalimantan Tengah dan Kota Palangka Raya. 
Terdapat enam agama yang hingga kini tetap eksis diantaranya; Islam, Kristen, Katolik, Hindu/Hindu Kaharingan, Budha dan Konghucu. Agama Hindu sebagai salah satu agama yang eksis di Kota Palangka Raya memiliki latar belakang varian budaya yang berbeda, Hindu Jawa salah satunya.

Berdasarkan data Badan Pusat Statistik Kota Palangka Raya, komposisi pemeluk agama terbesar di Kota Palangka Raya adalah agama Islam dengan jumlah pemeluknya 178.190 jiwa, Kristen 68.095 jiwa, Katolik 5.055 jiwa, Hindu 3.622 jiwa, Budha 445 jiwa, Konghucu 13 jiwa dan aliran kepercayaan 32 jiwa (BPS, 2017). Khusus data untuk umat Hindu memiliki perbedaan yang cukup signifikan dibandingkan dengan data yang dikeluarkan oleh Pembimas Hindu Kementerian Agama Provinsi Kalimantan Tengah yang mencatat jumlah pemeluk Hindu adalah 7.957 Jiwa (Hartati, 2015). Ketimpangan data ini menurut Ratno Gunawan (Penyuluh Agama Hindu Kota Palangka Raya) (Wawancara, 20 September 2018) disebabkan tidak dicatatkan secara detail jumlah jiwa umat Hindu di Kota Palangka Raya, selain itu jumlah mahasiswa yang menempuh pendidikan baik di UPR (Universitas Palangka Raya) dan Institut Agama Hindu Negeri Tampung Penyang (IAHN-TP) tidak menjadi bagian penduduk Kota Palangka Raya. Namun, berdasarkan penghitungan data oleh Pembimas Hindu Kota Palangka Raya, jumlah keseluruhan mahasiswa yang menempuh pendidikan di Kota Palangka Raya masuk dalam data jumlah umat Hindu Kota Palangka Raya.

\section{Historitas Pandu Jawi di Kota Palangka Raya}

Paguyuban Hindu Jawi merupakan bentuk kehidupan bersama dimana anggotaanggotanya diikat oleh hubungan batin yang murni dan bersifat alamiah berdasarkan kedaerahan (Jawa) dan agama Hindu. Paguyuban ini murni sebagai wadah pertemuan antar umat Hindu Jawa yang meskipun dalam konteks latarbelakang daerah asal (Jawa) sedikit berbeda, ada yang berasal dari Jepara, Banyuwangi, Malang dan Boyolali. Konsekuensinya kemudian baik dari tradisi upacara maupun cengkok tembang atau kidungnya terdapat perbedaan. Tetapi prinsip besar yang mereka pegang adalah sama-sama berasal dari Jawa, beragama Hindu dan berasaskan handarbeni.

Pandu Jawi didirikan pada Bulan Juli 2015. Cikal bakal pendirian Paguyuban Hindu Jawi menurut Mujiyono (wawancara, 3 September 2018) memiliki cerita yang cukup panjang, diawali rangkaian "kebetulan" yang menumbuhkan rasa kangen sesama Jawane. Akhirnya rasa kangen-kangenan itu terakumulasi menjadi rencana pendirian komunitas Hindu Jawa, embrio ide ini telah muncul kurang lebih sekitar tahun 2005/2006. Embrio mengembang saat beberapa orang dari umat Hindu Jawa saling kunjung-mengunjungi pada hari-hari senggang, seperti hari Sabtu-Minggu maupun hari-hari libur lainnya. Pertemuan-pertemuan itu pula terjadi saat ritual- 
ritual keagamaan Hindu Jawa, misalnya saat slametan seperti; upacara kelahiran bayi, ruwahan, persembahyangan di Pura dan lain-lain.

Semangat kerinduan saling kunjung-mengunjungi ketika hari-hari senggang dan pelaksanaan ritus-ritus slametan diantara orang-orang Hindu Jawa menjadi pemantik berdirinya Paguyuban Hindu Jawi. Tatap muka melalui pertemuan semacam itu membangkitkan emosi keagamaan untuk sedikit mengenang tradisi Hindu Jawa yang pernah dicecap didaerah asalnya. Mujiyono (wawancara, 3 September 2018) menuturkan :

“...pertemuan-pertemuan ini didasari oleh rasa (emosi) keagamaan yang sama. Maksudnya sebagai orang Jawa kami memiliki kerinduan akan nilai-nilai tradisi Jawa dalam implementasi agama Hindu, misalnya: kidung, sarana upakara. Meskipun kami memiliki latar belakang dari daerah Jawa yang berbeda, tetapi hal itu bukan sesuatu yang dapat menghalangi untuk membangun sebuah komunitas...”.

Selain memenuhi rasa "emosi keagamaan" sebagaimana diungkapkan oleh Mujiyono, Handoko (wawancara, 28 Agustus 2016) memberikan alasan kebutuhan akan kerabat yang memiliki tradisi yang sepaham menjadi salah satu alasan penting mengapa Paguyuban Hindu Jawi dibentuk. Terlebih bukan sebuah hal yang aneh bila membentuk komunitas Hindu Jawa, meskipun telah ada suka-duka dengan tempek-tempek-nya yang menaungi umat Hindu Jawa dan Bali, tetapi model tempek ini secara batin belum dapat memuaskan, sebab bagaimanapun tradisi ke-Hindu Jawa-an adalah hal penting pula untuk dilestarikan. Oleh sebab itu, jalan terbaik adalah bagaimana upaya umat Hindu Jawa di Kota Palangka Raya dapat bertemu dan berkumpul secara rutin, yaitu dengan membentuk paguyuban. Tetapi, modal pertemuan dan saling kunjung mengunjungi hingga kebutuhan akan pentingnya kerabat yang memiliki latar budaya sama ternyata belumlah cukup menjadi semangat untuk membangun Paguyuban Hindu Jawa, sampai akhirnya menemukan momentum dibulan ketiga tahun 2014 dalam bentuk "insiden" yang kemudian kembali menjadi "api semangat" terbentuknya Paguyuban Hindu Jawi.

Ketika itu putra dari Sunarto, salah satu anggota Paguyuban Hindu Jawi meningggal dunia dan Sunarto merasa bingung harus meminta bantuan untuk melakukan upacara penguburan. Sementara Sunarto sendiri tidak tercatat sebagi salah satu anggota tempek yang ada di Kota Palangka Raya. Di tengah “insiden” meninggal putranya tersebut, Sunarto kemudian menghubungi Mujiyono yang telah masuk dan tercatat sebagai anggota tempek II, sehingga ia memiliki kedekatan dengan orang-orang Bali, khususnya yang berada dilingkungan Pura Pitamaha yang mayoritas adalah tempek II. Mujiyono kemudian menyarankan dan mendampingi Sunarto untuk meminta bantuan kepada Ibu Rada yang 
memiliki pengetahuan tentang pembuatan upakara dengan ciri khas Bali. Selanjutnya Ibu Rada menyanggupi dan membuatkan sedikit upakara untuk upacara penguburan putra Sunarto.

Pelajaran sebagaimana yang dialami oleh Sunarto berlanjut menjadi bahan diskusi kecil yang lebih serius dirumah Mujiyono, yang dilakukan setelah 40 (empat puluh) hari meninggalnya putra Sunarto. Diskusi kecil ini diprakarsai oleh Sunarto sendiri, Budi Purnomo dan Mujiyono sebagai tuan rumah (wawancara, 7, 10 dan 12 September 2018). Ketiga orang ini merupakan sesepuh Paguyuban Hindu Jawi yang bekerja di Sekolah Tinggi Agama Hindu Negeri Tampung Penyang (STAHN-TP) yang kini telah menjadi Institut Agama Hindu Negeri (IAHN) Tampung Penyang. Budi Purnomo dan Mujiyono adalah dosen dan Sunarto sebagai cleaning service. Dalam diskusi tersebut, selain karena insiden meninggalnya putra dari Sunarto, terdapat perkembangan pertimbangan-pertimbangan lain yang menjadi latar belakang pembentukan Paguyuban Hindu Jawi, sebagaimana diutarakan oleh Sunarto (wawancara, 12 September 2018) yaitu;

“...kita sebagai perantau, dalam hal ini memerlukan wadah. Ibaratkan nasi jika nggak ada piringnya, bagaimana kita menikmati makanan. Wadah ini penting untuk kita dapat membikin dan menikmati sesuatu. Selama ini kan ndak menentu pertemuan kita, paling-paling kalo ada undangan saja. Maksudnya kalo ada wadahnya jadi bisa rutin ketemunya"."....Kita ini nggk luput dari maslah sakral atau kematian, saya mengalami waktu anak saya meninggal. Saya ketemu dengan Romo Muji, Pak Budi dan Bu Rada. Hal-hal ini yang mendasari saya semangat untuk membentuk wadah ini. Selain itu, Untuk mempertebal iman, anak2 cucu saya jangan sampe tidak paham dengan Hindu (Jawa)..." "...Melihat aset dalam artian Sumber Daya Manusia (SDM) Jawa Hindu di Palangka Raya sudah banyak, saya mengusulkan kepada Pak Muji atau Romo Muji untuk membentuk sebuah wadah, yang kita kenal sekarang dengan istilah Paguyuban Hindu Jawi. Meskipun saya Cuma modal semangat, minim pengetahuan dan pemahaman Agama Hindu. Tapi bagi saya itulah modal utama saya untuk mendesak atau mendorong Romo Muji dan Pak Budi Purnomo untuk segera membentuk wadah yang dapat mengayomi umat Hindu Jawa...".

Sunarto adalah orang yang penuh semangat, ketika peneliti mewawancarai. Ekspresi wajahnya menampakkan harapan besar yang digantungkan keluarganya kepada Pandu Jawi. Sebab latar belakang istrinya adalah seorang nasrani (Kristen) sehingga minim pengetahuan agama Hindu. Dalam beberapa kegiatan Paguyuban Hindu Jawi, baik persembahyangan bersama dalam rangka arisan dan slametan, pertanyaan-pertanyaan seputar acara-acara tersebut acap muncul dari istrinya, konsekuensinya ia harus menjelaskan secara perlahan-lahan dan berulang-ulang. Bahkan secara khusus ia mengajarkan cara mengucapkan mantra sebelum memulai pekerjaan, khususnya berdagang. Kebetulan istrinya adalah pedagang sayur mayur dan hasil pertanian lainnya disebuah pasar di Kota Palangka Raya. Om $\bar{a}$ wișwani amṛta saubhagāni, adalah mantra yang pernah dianjurkan oleh Mujoyono (Romo Muji), kepada 
Sunarto untuk memperoleh keberuntungan yang berlimpah, dan kemudian mantra ini ia ajarkan kepada istrinya.

Dari paparan tentang cerita-cerita para tokoh Pandu Jawi, dapat dipahami beberapa hal penting yang kemudian menjadi pokok ide pembentukan Paguyban Hindu Jawi yaitu; (1) adanya rasa saling kangen terhadap nilai-nilai Hindu Jawa yang pernah mereka cecap didaerah asalnya; (2) adanya kesamaan latar belakang tradisi, budaya Hindu Jawa yang harus tetap dilestarikan; (3) rasa senasib sepenanggungan sebagai sesama perantau dan memiliki keyakinan yang sama yaitu agama Hindu.

\section{Struktur Organisasi dan Pengelolaan Paguyuban Hindu Jawi}

Paguyuban Hindu Jawi merupakan organisasi yang bernaung di bawah lembaga PHDI Provinsi Kalimantan Tengah. Memiliki unsur kepengurusan; penasehat, ketua, wakil ketua, sekretaris, bendahara. Sedangkan masa bhakti kepengurusan Paguyuban Hindu Jawi selama 3 tahun dan dapat dipilih kembali untuk periode berikutnya berdasarkan musyawarah dan mufakat. Musyawarah dilaksanakan setiap bulan bersamaan dengan kegiatan arisan yang dihadiri oleh seluruh anggota Pandu Jawi. Agenda-agenda dalam kegiatan tersebut adalah dharmawacana, arisan, pembahasan hal-hal yang berkaitan dengan sosial keagamaan serta informasi lainnya yang berkaitan dengan kebutuhan organisasi. Sedangkan musyawarah untuk pergantian pengurus dilaksanakan setelah berakhirnya masa bhakti kepengurusan Paguyuban Hindu Jawi, melalui musyawarah dan mufakat.

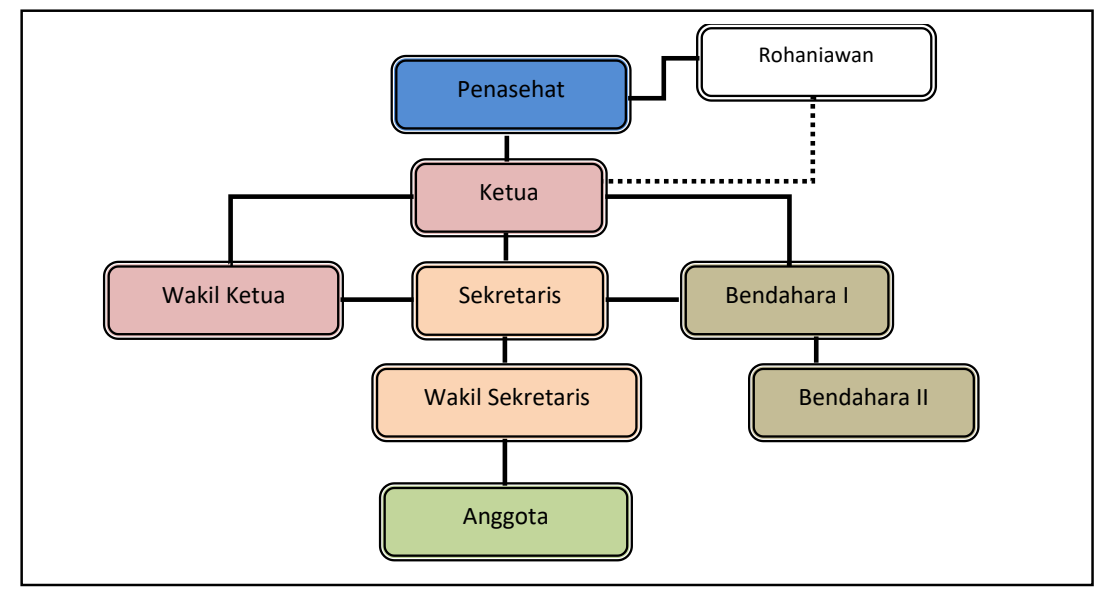

Struktur Organisasi Paguyuban Hindu Jawi

\begin{tabular}{lll} 
Keterangan $:$ & & Interaksi Langsung \\
\cline { 2 - 3 } $\begin{array}{l}\text { Penjelasan Bagan : } \\
\text { Rohaniawan }\end{array}$ & & Interaksi tidak langsung \\
Penasehat & $:$ & Dr. Mujiyono, S.Ag,.M.Ag. \\
Ketua & $:$ & Budi Purnomo, SH,.M.Si. \\
Wakil Ketua & $:$ & Handoko, S.Ag,.M.Si. \\
& & Aipda. Joko Maryanto, SH.
\end{tabular}


Sekretaris Puspo Renan Joyo, S.Ag,.M.Pd.H

Wakil Sekretaris Hermi Munanto

Bendahara I : Parmanto, S.Ag

Pengelolaan Paguyuban Hindu Jawi disesuaikan dengan AD/ART yang mengatur beberapa hal yaitu; Bab II pasal 2 dalam Anggaran Dasar menjelaskan asas Paguyuban Hindu Jawi yaitu; Organisasi yang berasaskan kekeluargaan dan bernafaskan ajaran agama Hindu. Sedangkan dalam Bab III pasal 3 menjelaskan tentang sifat organisasi yang terbuka dan mandiri, pasal 4 menerangkan tujuan organisasi ini adalah sebagai sarana belajar dan pembinaan, menyatukan pemikiran serta membangun rasa kekeluargaan antar sesama warga Paguyuban Hindu Jawi dan Pasal 5 menerangkan fungsi Paguyuban Hindu Jawi untuk mewujudkan sikap asih lan handarbeni antar warga Paguyuban Hindu Jawi.

Mengenai keanggotaan Paguyuban Hindu Jawi di jelaskan pada Bab IV pasal 6 yang menejelaskan anggota Paguyuban Hindu Jawi adalah warga Hindu yang berasal dari suku Jawa atau yang ada hubungannya dengan silsilah keluarga, yang dengan kesadaran sendiri menyatakan menjadi anggota Paguyuban Hindu Jawi. Hingga kini jumlah keanggotaan Pandu Jawi berjumlah $25 \mathrm{KK}$. Sedangkan pengelolaan dana keuangan organisasi diperoleh dari; (a) iuran anggota baru; (b) iuran wajib bulanan; (c) iuran wajib tahunan dan (d) sumbangan suka rela.

Meskipun secara formal Paguyuban Hindu Jawi memiliki tata aturan dalam pengelolaan organisasi, tetapi tetap mengutamakan rasa kekeluargaan. Hal ini dijelaskan oleh Handoko (Ketua Pandu Jawi) (wawancara, 26 Agustus 2018) ketika ditanyakan pengelolaan atau manajemen Paguyuban Hindu Jawi. Menurut penuturannya selama ini berjalan secara alamiah. Maksudnya tidak kaku, mengalir tanpa menggunakan konsep-konsep majemen modern, sebagaimana paguyuban atau organisasi lainnya. Walaupun telah memiliki Anggaran Dasar (AD) dan Rumah Tangga (ART) namun dalam penerapannya hal itu sangat fleksibel dan berasaskan kekeluargaan.

Menyimak pendapat ketua Paguyuban Hindu Jawi tersebut, nilai hidup Jawa seperti kekeluargaan, senasib sepenanggungan, "mangan ora mangan sing penting kumpul” tetap menjadi pegangan dalam menjalankan prinsip-prinsip organisasi. Meskipun tidak jarang diskusi sengit acap terjadi, khususnya ketika mengulas persoalan legalitas, maksudnya apakah Paguyuban Hindu Jawi harus didaftarkan ke Kementerian Hukum dan HAM untuk memperoleh akta notaris atau minimal ke Pemerintah Daerah (Pemda) khususnya pada Dinas Kesatuan Bangsa Politik dan Perlindungan Masyarakat (Kesbangpolinmas) Kota Palangka Raya. Perdebatan-perdebatan itu hingga kini belum menemui ujungnya. Namun melalui 
pengelolaan yang alamiah Paguyuban Hindu Jawi tetap mampu menjaga persatuannya dengan sangat baik.

Perdebatan kecil lainnya menurut penuturan Sunarto misalnya keberadaan konsumsi yang sedikit jor-joran saat pelaksanaan arisan maupun kegiatan slametan. Hal ini dikemukan Sunarto (wawancara, 7 September 2018) sebagai berikut.

“...Dalam paguyuban kami, khususnya dalam pertemuan-pertemuan, konsumsi nggk usah terlalu bermewah-mewah. Tapi kalo kita mau sembahyangan (istilah yang digunakan Sunarto, ketika ada acara kumpul-kumpul, yang pasti diisi dengan persembahyangan) rasanya rejeki ada. Masalah konsumsi iku sama mas Yoyok sering diprotes. Menurutnya masalah konsumsi seadanya aja, jangan diada-adakan. Tapi bagi kami tidak diada-adakan. Pengalaman saya, sepuluh hari mau sembahyangan. Keuntungan mamahnya dalam sehari tidak kurang dari 500. 000. Iki jujur lo mas...”.

Warna warni pengelolaan Paguyuban Hindu Jawi khususnya terkait dengan "kumpulkumpul" yang berkonsekuensi terhadap ketersediaan konsumsi tidak lepas dari kritikan diantara internal Paguyuban Hindu Jawi. Tetapi kritikan-kritian ini sangatlah wajar, mengingat latar belakang para anggota tidak semuanya menjadi pegawai, tetapi sangat variatif. Ada yang berlatar belakang petani, buruh dan pedagang. Ada sebuah kekhawatiran diantara anggota Paguyuban Hindu Jawi tentang biaya konsumsi yang disediakan bagi tuan rumah, intinya harus tersedia solusi agar acara atau kumpul-kumpul yang diadakan itu tidak membebani para anggotanya. Tetapi, hal ini ditampik oleh sesepuh Paguyuban Hindu Jawi seperti Mujiyono, Budi Purnomo dan Handoko. Mereka mempersiapkan konsumsi dalam acara-acara tertentu bukan saja bertujuan untuk mengundang anggota melainkan para tetangganya yang memiliki latar belakang agama, suku dan budaya yang berbeda. Artinya jalinan keakraban dapat terawat dengan lingkungannya saat acara yang mereka gelar.

\section{Aktivitas Paguyuban Hindu Jawi di Kota Palangka Raya}

Aktivitas Paguyuban Hindu Jawi di Kota Palangka Raya dilakukan secara eksternal dan internal. Aktivitas eksternal diarahkan pada kegiatan diluar kepentingan paguyuban, sedangkan aktivitas internal adalah kegiatan yang memiliki hubunagn dengan pengembangan paguyuban. Ulasan tentang aktivitas eksternal maupun internal diulas sebagai berikut.

\section{Aktivitas Eksternal Paguyuban Hindu Jawi}

\section{Pelatihan fermentasi makanan ternak}

Umat Hindu, khususnya Kaharingan di Kalimantan Tengah mayoritas adalah petani, meskipun petani, sebagian dari mereka ada yang memanfaatkan waktu sisa pasca berladang untuk meningkatkan pendapatannya dengan memelihara ternak. Seperti sapi, ayam dan babi. Berdasarkan pengamatan peneliti, babi adalah pilihan yang paling dominan untuk dipelihara. 
Mengingat harga daging babi dipasaran mencapai Rp. 65.000,- sampai dengan Rp. 70.000,/kg. Selain sebagai konsumsi, babi acap dipergunakan untuk kepentingan upacara agama. Hal ini pula yang menyebabkan harga babi stabil dan cenderung mengalami kenaikan. Selain itu, makanan babi seperti dedak, ampas tahu maupun konsentrat mengalami peningkatan hampir setiap 3 bulan. Problem meningkatnya makanan ini acap menghambat niat petani ataupun peternak untuk memelihara ternak secara berkelanjutan. Masalah ini memperoleh perhatian dari Paguyuban Hinndu Jawi melalui peran Budi Purnomo berupaya membantu mereka khususnya dalam menyediakan makanan ternak dengan prinsip murah meriah, memanfaatkan sisa-sisa sampah rumah tangga, tanaman dilingkungan rumah atau ladangnya seperti batang pisang, daun-daunan dan keladi yang kemudian diolah menjadi makanan ternak dengan cara fermentasi. Pelatihan fermentasi makanan babi ini mendapat respon baik dibeberapa daerah, seperti di Desa Tangkiling, Sigi dan Bawan serta Katingan.

Budi Purnomo menerangkan, dalam memberikan pelatihan makanan ternak acap menyelipkan ajaran-ajaran Hindu dan sejarah agama Hindu. Terutama penyebab Hindu mengalami keruntuhan, seperti musnah secara perlahan, penyebab salah satunya karena ekonomi yang tidak kuat. Pun demikian jika dihubungkan dengan banyak umat kaharingan beralih agama karena alasan pertama adalah ekonomi. Kelemahan ini acap menjadi senjata para misionaris, seperti membuat kabar mahalnya biaya upacara Tiwah. Singkatnya kalau tidak kaya atau memiliki uang banyak tidak dapat meniwahkan orang tua atau saudara-saudaranya. Meskipun kini upacara Tiwah dapat dilakukan secara kolektif, tetapi tetap membutuhkan biaya. Kenyataan ini kemudian menggelayut dalam pikiran dan benaknya, oleh sebab itu ide pembuatan fermentasi makanan babi ini salah satu upaya memandirikan umat Kaharingan.

\section{Gotong Royong}

Paguyuban Hindu Jawi, sebagai komunitas umat Hindu Jawa melaksanakan gotong royong dibeberapa tempat di Kota Palangka Raya, seperti di Pura dan Balai Basarah. Gotong royong ini merupakan bentuk kerja-bhakti yang dilakukan secara bersama-sama dengan tempek-tempek, Kementerian Agama Provinsi Kalimantan Tengah diwakili oleh Pembimas Hindu dan Kemenag Kota Palangka Raya dengan para penyuluh Agama Hindu. Selain gotong royong dalam bentuk kerja-bhakti, gotong-royong dalam bentuk tolong menolong untuk kepentingan perseorangan dalam hal kesusahan ataupun memerlukan curahan tenaga dalam menyelesaikan pekerjaannya juga dilakukan, misalnya merehab rumah, pindah rumah termasuk dalam hal kedukaan. Gotong royong, untuk kepentingan bersama maupun perorangan menurut penuturan Gelar Sumbogo Peni (wawancara, 4 oktober 2018) dilakukan secara 
insidentil. Artinya tidak dilakukan secara pasti dan terjadwal, melainkan disesuaikan dengan momen-momen tertentu, seperti adanya upacara di Pura dan ritual di Balai Basarah. Sedangkan untuk gotong-royong yang bersifat pribadi, menurut Puspo Renan Joyo, (wawancara, 26 Agustus 2018) dilakukan untuk memenuhi undangan atau permintaan dari para sahabat, misalnya ketika dalam sebuah keluarga melaksanakan upacara agama seperti; kelahiran, membuat fundasi rumah, membongkar rumah dan lain-lain yang lebih bersifat urusan pribadi.

\section{Dharma Wacana/Pandehen dalam Acara Basarah}

Dharma wacana atau dalam Hindu Kaharingan disebut dengan pandehen memiliki maksud, tujuan dan makna yang serupa yaitu, menyampaikan atau mengulas hal-hal yang berkaitan dengan dharma (agama). Tetapi dharma wacana dan pandehen memiliki perbedaan konteks penggunaan. Penyebutan dharma wacana adalah ketika persembahyangan dengan kekhasan Hindu, misalnya di Pura. Sementara penggunaan kata pandehen adalah saat persembahyangan bernuansa Kaharingan, seperti basarah. Dharma wacana merupakan salah satu sistem pewarisan ajaran agama Hindu seperti yang telah ditetapkan oleh Parisadha Hindu Dharma Indonesia (PHDI) (Sartini, 2015, p. 222). Sedangkan pandehen adalah penjelasan dari ayat-ayat Panaturan yang dibacakan saat persembahyangan Umat Hindu Kaharingan (Penyusun, Bahan Ajar Acara Agama Hindu Kaharingan, 2003, p. 38).

Pandehen wajib ada dalam rangkaian acara basarah. Biasanya sebelum pelaksanaan basarah di mulai, pemandu akan membacakan urutan pelaksanaan basarah, yang salah satunya adalah membacakan petugas yang telah ditunjuk untuk memberikan pandehen. Dalam persembahyangan basarah, orang yang acap menjadi "langganan" untuk memberikan pandehen salah satunya adalah Budi Purnomo. Alasan sederhana acap ditunjukknya Budi Purnomo sebagai orang yang memberikan pandehen karena kemampuannya menjelaskan ayatayat Panaturan secara sederhana dan mudah dipahami. Penjelasan ayat-ayat Panaturan oleh Budi Purnomo biasanya dikaitkan dengan ajaran Hindu secara umum. Hal ini kemudian yang menjadi menarik bagi peserta basarah yang tidak hanya umat Hindu Kaharingan, tetapi terdapat pula umat Hindu Bali dan Jawa.

Budi Purnomo sebagai penasehat Paguyuban Hindu Jawi, tidak hanya memberikan pandehen/dharma wacana dalam lingkup Kota Palangka Raya. Melainkan ia kerap diundang keluar daerah, seperti Kabupaten Katingan, Pulang Pisau, Gunung Mas, Barito Utara, Murung Raya, Sampit dan lain sebagainya. Bahkan secara khusus, di Kabupaten Katingan dan Gunung Mas, ia diundang selama satu minggu untuk memberikan pandehen dalam acara Haring Kaharing yang diselenggarakan oleh Pemerintah Daerah Kabupaten Katingan dan Gunung Mas. Selain memberi pandehen, ia acap diundang dalam pertemuan tokoh-tokoh Hindu di 
Kabupaten Pulang Pisau yang diselenggarakan oleh penyelenggara Bimas Hindu Kementerian Agama Kabupaten Pulang Pisau.

\section{Arisan}

Model arisan kini menjadi tren, tidak sedikit keluarga, instansi, organisasi sosial menyelenggarakan arisan. Tujuannyapun beraneka macam, memiliki tabungan atau simpanan salah satunya. Tren model arisan ini menjangkit pula pada berbagai perkumpulan-perkumpulan yang berazaskan kesuka-dukaan. Arisan dipergunakan sebagai momen untuk lebih mendekatkan diri antar anggota agar lebih akrab. Terlebih jika terdapat anggota baru yang masuk sebagai bagian dari perkumpulan itu, suasan perkenalan acap mengiringi setiap akan dimulainya acara. Berdasarkan pengamatan saya, hampir keseluruhan perkumpulan masyarakat Hindu di Kota Palangka Raya memiliki tradisi arisan. Demikian halnya dengan Paguyuban Hindu Jawi, setiap bulannya paguyuban ini melaksanakan arisan.

Berdasarkan wawancara dengan Budi Purnomo, kegiatan arisan yang dilakukan secara rutin, kini telah berkembang menjadi dana pinjaman bergulir untuk para anggota Pandu Jawi. Dana bergulir ini menurut beberapa anggota seperti, Puspo Renan Joyo, Sunarto dan Roni Harjanto sangat signifikan membantu kebutuhan-kebutuhan dadakan, misalnya ketika salah satu dari keluarga mereka ada yang sakit. Dalam arisan tersebut juga didiskusikan rencanarencana Pandu Jawi kedepan, misalnya penambahan anggota yang dapat menjangkau seluruh Kabupaten di Kalimantan Tengah. Hal ini penting mengingat sebaran umat Hindu Jawa cukup merata di Kalimantan Tengah, seperti di Kabupaten Pulang Pisau, Kapuas, Lamandau dan Pangkalan Bun.

\section{Aktivitas Internal Paguyuban Hindu Jawi}

\section{Ritus Slametan}

Slametan merupakan esensi perwujudan agam Jawa. Slametan adalah simbol wujud bhakti orang Jawa disebut pangastuti (puja, bhakti) (Endraswara, 2016, pp. 31-32). Slametan secara garis besarnya terbagi dalam empat jenis: (1) yang berkisar sekitar krisis-krisis kehidupan - kelahiran, khitanan, perkawinan dan kematian; (2) yang ada hubungannya dengan hari-hari raya; (3) yang ada sangkut pautnya dengan integerasi sosial desa, bersih desa; (4) slametan sela yang diselenggarakan dalam waktu yang tidak tetap, tergantung kepada kejadian luar biasa yang dialami seseorang seperti; pindah tempat, ganti nama, sakit, terkena tenung, dan sebagainya (Geertz, 1983, p. 38). Empat jenis slametan sebagaimana dinyatakan oleh Geertz, tidak semua dilakukan atau dibuat menjadi acara peringatan oleh umat Hindu Jawa di 
Kota Palangka Raya. Dalam rangka itu, umat Hindu Jawa hanya melaksanakan slametan kelahiran dan kematian.

\section{Slametan Kelahiran Bayi (Babaran, Brokahan, Puputan dan Selapanan)}

Slametan dalam rangka kelahiran yang pernah dilakukan Paguyuban Hindu Jawi di Kota Palangka Raya adalah babaran atau brokohan. Babaran atau brokohan merupakan salah satu upacara tradisi Jawa untuk menyambut kelahiran bayi yang dilaksanakan sehari setelah bayi lahir. Babaran menurut penuturan Jarot Widi Atmoko, (wawancara, 24 Oktober 2018) berbeda pengertian dengan dengan brokohan. Babaran itu, adalah saat upacara penanaman plasenta atau ari-ari si bayi, sementara brokohan itu, ketika pemberian nama sekaligus mengesahkan nama si bayi, namun kini kedua jenis slametan ini disamakan sebab waktu pelaksanaanya biasanya bersamaan, jikalau berbeda hanya berselang sehari atau dua hari saja.

Ari-ari yang dianggap sebagai saudara sibayi diperlakukan dengan penghormatan, perlakukan ini terlihat dari cara membawanya, digendong laiknya menggendong sibayi. Terdapat beberapa perlengkapan yang dipergunakan dalam menanam ari-ari ini, seperti; periuk, tempurung, kunir, daun alas, kembang gepak, jendul, gerek pethek, jarum (Hindu, 2009, pp. 26-27). Bagi orang Jawa ari-ari memiliki jasa yang cukup besar sebagai batir bayi (teman bayi) sejak dalam kandungan. Oleh karena itu sejak fungsi utama ari-ari berakhir ketika bayi lahir, organ ini akan tetap di rawat dan di kubur sedemikian rupa agar tidak di makan binatang atau pun membusuk di tempat sampah. Upacara mendhem ari-ari ini biasanya dilakukan oleh sang ayah, berada di dekat pintu utama rumah, diberi pagar bambu dan penerangan berupa lampu minyak selama 35 hari (selapan) (Widyaningrum, 2017, p. 5).

Sementara brokohan sendiri berasal dari kata barokah-an, yang artinya memohon berkah dan keselamatan atas kelahiran bayi. Dalam acara ini biasanya para tetangga dekat dan sanak saudara berdatangan berkumpul sebagai tanda turut bahagia atas kelahiran bayi yang dapat berjalan dengan lancar. Tidak sedikit para tetangga membawa bermacam oleh-oleh berupa perlengkapan bayi, termasuk deterjen, sabun dan makanan untuk keluarga yang melahirkan.

Slametan seperti babaran atau brokohan pernah dilaksanakan oleh Roni Harjanto, anggota Paguyuban Hindu Jawi yang beralamat di Kereng Bangkirai Kecamatan Sebangau Kota Palangka Raya. Babaran atau brokohan yang dilaksanannya sangat sederhana. Tidak seperti di Jawa yang lengkap dengan aneka umba rampenya. Kesederhanaan umba rampe terlihat dari sajian berupa kembang setaman, yang diletakkan pada sebuah gayung kecil berisi air. Selain itu, sarana pendukung lainnya adalah jajan pasar, bubur sejumlah lima piring kecil, satu piring bubur berwarna hitam menempati posisi tengah, sedangkan empat piring lainnya 
berada disudut timur, selatan, barat dan utara. Bubur-bubur ini ditempatkan di atas meja kecil. Posisi bubur yang berada sesuai arah tersebut menggambarkan saudara empat (dulur papat). Sedangkan yang ditengah melambangkan sibayi. Selain bubur, kopi dan teh juga disediakan dalam slametan ini.

Selain babaran atau brokohan, salametan puputan juga dilakukan sebagai lanjutan dari babaran dan brokohan. Puputan dilaksanakan saat tali pusar bayi terpisah dari perut bayi. Tujuannya memohon pada Hyang Widhi agar si anak yang telah puput puser selalu mendapatkan anugerah, diberi keselamatan dan kesehatan. Ada juga yang menggabung upacara puputan ini dengan selapanan. Selapanan dilakukan 35 hari (selapan) setelah kelahiran bayi. Upacara selapanan dilangsungkan dengan rangkaian acara bancakan weton (kenduri hari kelahiran) pemotongan rambut bayi hingga gundul dan pemotongan kuku bayi. Pemotongan rambut dan kuku ini bertujuan untuk menjaga kesehatan bayi agar kulit kepala dan jari bayi tetap bersih, upacara ini sekaligus sebuah doa agar si bayi kedepannya diberikan kesehatan.

\section{Wetonan}

Bagi umat Hindu Jawa, weton merupakan sesuatu yang tidak asing. Secara etimologi weton berasal dari kata wetu yang berarti lahir atau keluar. Sehingga weton atau wetonan adalah jenis slametan untuk memperingati, mengenang hari kelahiran. Tujuannya bersyukur kepada Hyang Widhi karena telah diberikan kesehatan dan keselamatan.

Handoko sebagai ketua Paguyuban Hindu Jawi acap melaksanakan wetonan putranya. Istilah yang ia kemukakan adalah sewinduan. Dalam rangka sewinduan putranya tersebut beliau mengadakan slametan dengan upacara yang sangat sederhana, tanpa meninggalkan tujuan dari upacara tersebut. Slametan sewinduan yang dilakukan Handoko menggunakan sarana utama seperti pada umumnya umat Hindu Jawa. Buah-buahan, ayam ingkung, tumpeng kuning, jajan pasar adalah acesoris penting yang harus tersedia dalam slametan ini. Aneka buah yang dijadikan umba rampe adalah jeruk, pisang, apel. Buah utama dalam slametan ini adalah pisang. Jika memungkinkan adalah buah pisang raja. Pisang raja merupakan simbol keadilan, sehingga permohonan yang diungkapkan agar putra yang bersangkutan memiliki watak seperti raja; yakni adil, berbudi luhur, dan tepat janji. Penggunaan pisang sebagai umba rampe juga dikaitkan dengan pelajaran tentang etika kehidupan, yaitu agar seseorang dapat hidup sesuai dengan watak pisang. Ia dapat hidup ajur-ajer, selalau menyesuaikan diri dengan lingkungan (Achmad, 2018, pp. 139-140). Sedangkan untuk ingkung ayam menurut penuturan Handoko (wawancara, 28 Agustus 2018) memiliki makna bahwa manusia itu harus meniru sifat postif ayam, ayam tersebut ketika diberi makan tidak langsung dimakan, melainkan dipilih dahulu. 
Maksudnya dalam wetonan menggunakan ingkung ayam agar seseorang yang diupacarai memiliki kemampuan yang baik dalam memilah dan memilih sesuatu. Demikian halnya dengan tumpeng, melambangkan gunung. Sedangkan warna kuning adalah warna keberlimpahan rejeki.

\section{Slametan Kematian}

\section{Ruwahan}

Ruwahan, istilah ini lahir karena pengaruh Islam. Bagi orang Jawa yang beragama Hindu slametan jenis ini dikategorikan sebagai pitra yadnya. Dahulu, sebelum masuk agama Hindu Pitra Yadnya diadakan pada hari ke 40, 100 dan 1000, setelah orang meninggal. Tetapi sekarang telah disesuaikan dengan ajaran Hindu, yaitu ke-42 (jumlah hari, pasaran dan pawukon), hari ke 108 (potongan tulang manusia sebanyak 108) dan hari ke-1000. Angka seribu ini memiliki pengertian khusus, yaitu angka 1 (satu) dan 3 angka NOL berjajar berurutan dalam satu kesatuan. Arti bilangan 3 angka NOL adalah tiga unsure jagat alait, yaitu jasmani, rohani dan Atman, diharapkan kembali ke NOL (habis), hingga yang tersisa hanya 1 (satu), yaitu simbol dari Hyang Maha Tunggal. Bagi orang Jawa 'Pitra Yadnya' merupakan upacara yang tak boleh dilalaikan (Suripto, 2006, pp. 60-70).

Ruwahan di Kota Palangka Raya pernah dilaksanakan di rumah Mujiyono, Joko dan Ketut Mahendra. Pada bulan ruwah dipercaya roh para leluhur yang telah meninggal dunia banyak pulang ke rumah. Sehingga bulan ini juga memiliki arti "meruhi arwah". Ketika ruwahan, dalam tradisi Hindu Jawa dilakukan nyadran. Tradisi ini berasal dari Hindu kuno sebelum masuk agama Islam. Dahulu upacara ini disebut dengan Sraddha, acap dilakukan umat Hindu di pulau Jawa untuk mengenang arwah seseorang yang meninggal. Hingga kini ruwahan atau nyadran masih banyak dilakukan oleh masyarakat Jawa.

Sesaji yang ada dalam ruwah adalah tumpeng, nasi gurih, nasi ambeng, ingkung, tukon pasar, ketan, kolak, apem, minuman, kemenyan, bunga dan bila memungkinkan bagi umat Hindu Jawa yang memahami tentang banten dipadukan dengan banten prayastita. Di Palangka Raya, tidak ditemukan penggunaan banten prayascita, oleh sebab itu sarana pokoknya tumpeng berwarna putih, ingkung ayam, tukon (jajan) pasar, ketan kolak, apem, minuman dan bunga ditambah beberapa canang sari yang lekat dengan pengaruh Hindu Bali.

\section{Basarah}

Basarah adalah persembahyangan yang menggunakan tradisi Kaharingan, bersumber dari Panaturan, Kitab Suci Hindu Kaharingan. Dalam Bahasa Sangiang, basarah mengandung arti penyerahan diri secara total kepada Tuhan (Ranying Hatalla) agar memperoleh perlindungan, diberkati dan memperoleh anugerahNya. Ada tiga jenis basarah yang dilakukan 
oleh umat Kaharingan; (1) Basarah perorangan yaitu berdo'a sendiri, menabur beras kuning, atau meletakkan telor ditempat-tempat yang sakral (keramat); (2) Basarah keluarga biasanya dikerjakan di rumah, waktunya disesuaikan dengan kebutuhan; (3) basarah umum diadakan di Balai Kaharingan, dihadiri banyak orang pada hari Kamis atau malam Jum'at. Dalam setiap basarah umat Kaharingan secara bersama-sama melantunkan kandayu atau nyayian suci. Ada beberapa jenis kandayu: a. kandayu Manyarah Sangku Tambak Raja; b. Kandayu Mantang Kayu Erang; c. Kandayu Parewei; d. Kandayu Mambuwur Behas Hambaruan. (Penyusun, Bahan Ajar Acara Agama Hindu Kaharingan, 2003) (Sugiyarto, 2016, p. 112).

Basarah yang dilakukan oleh Mujiyono adalah basarah keluarga, waktunya disesuaikan dengan kebutuhan. Kebetulan saat itu Mujiyono memperoleh rezeki lebih, sehingga sebagai ucapan syukur beliau melaksanakan basarah dirumahnya. Basarah inipun ramai dihadiri oleh pengunjung, khususnya keluarga besar Institut Agama Hindu Negeri Tampung Penyang (IAHN TP). Dalam kesempatan itu, ucapan terima kasih dan rasa bahagia sebagai salam pembuka (ujub) sebagai tuan rumah diungkapkan oleh Mujiyono atas kehadiran undangan. Dalam basarah diisi pula dengan pandehen (dharmawacana) atau siraman rohani, pandehen disampaikan oleh Budi Purnomo yang memiliki banyak pengetahuan tentang Kaharingan.

\section{Pembahasan Hasil Penelitian}

Aktivitas yang dilakukan oleh Paguyuban Hindu Jawi sebagaimana paparan hasil penelitian tersebut memiliki fungsi-fungsi tertentu. Fungsi ini berdampak pada eksistensi Hindu Jawa atau Paguyuban Hindu Jawi di Kota Palangka Raya. Fungsi aktivitas Paguyuban Hindu Jawi antara lain, sebagai penyangga sosial-budaya dan ekonomi.

\section{Penyangga Sosial}

Terdapat dua fungsi sosial yang secara manifes dapat diamati dari berbagai bentuk kegiatan yang dilakukan oleh Pandu Jawi di Palangka Raya. Pertama adalah integerasi sosial, dan kedua solidaritas sosial. Kedua fungsi penyangga sosial yaitu, solidaritas sosial dan integerasi sosial selanjutnya dipaparkan secara singkat sebagai berikut.

\section{Integerasi Sosial}

Kamus Besar Bahasa Indonesia mengartikan "integrasi” sebagai pembauran hingga menjadi kesatu (Penyusun, Kamus Besar Bahasa Indonesa Edisi III, 2005, p. 437). Kata "kesatuan" mengisyaratkan berbagai macam elemen yang berbeda satu sama lain mengalami proses pembauran. Fungsi integerasi sosial nampak dari kegiatan-kegiatan yang dilakukan dan diikuti oleh Paguyuban Hindu Jawi. Dalam konteks kegiatan yang dilakukan adalah melaksanakan pertemuan rutin atau arisan, melaksanakan slametan dan basarah. Kegiatan 
arisan mengintegrasikan secara internal anggota Paguyuban Hindu Jawi sehingga menciptakan kesatuan yang lebih erat diantara umat Hindu Jawa meskipun diantara mereka memiliki latar belakang budaya Jawa yang sedikit berbeda. Perbedaan latar belakang justeru menurut Sunarto adalah sebuah keindahan, sebagaimana penuturannya.

“...saya dari Jawa Timur tapi besar di Malang. Walaupun kami memeiliki latar belakang Budaya Hindu yang berbeda tapi itu menjadi seni. Misalnya perbedaan cengkok dalam kidung dan sarana upacara. Ini adalah modal kami menyikapi perbedaan Hindu sendiri. Sarana upacara, kalo Jawa Tengah lebih lengkap dari Jawa Timur. Jawa Timur daerah Malang, demikian juga dari tembangnya. Kalo Jawa Timur agak kelajuan. Kalo Jawa Tengah kalem. Gitu juga masalah sesajen. Jawa Tengah lebih lengkap dari Jawa Timur, kalo Jawa Timur sangat praktis, tanpa dupa dan bunga tidak apa-apa, tapi kalo Jawa tengah lengkap sarana sembahyangnya seperti Bali...'(wawancara, 2 September 2018).

Ada perbedaan sarana upakara, cengkok tembang bahkan mantra-mantra sebagaimana penuturan Sunarto, hal yang biasa bagi orang Jawa. perbedaan itu justeru sebagai modal untuk memperkaya khasanah pengetahuan mereka tentang Hindu Jawa. Hal ini acap mereka diskusikan dalam acara arisan. Arisan telah mengantarkan Pandu Jawi untuk berintegrasi di tengah latar belakang mereka yang beragam, meski disadari untuk melakukan integerasi secara eksternal kadang paguyuban ini membutuhkan kehati-hatian, mengingat situasi lingkungan yang berbeda deangan daerah asalnya. Lewis A. Coser berpendapat jika suatu komunitas itu teritegerasi dengan baik ada kecenderungan memiliki toleransi tau bahkan membiarkan suatu konflik. Sebaliknya apabila suatu komunitas tersebut lemah derajad integerasinya maka biasanya cenderung bersikap berhati-hati terhadap kemingkinan munculnya suatu konflik (Poerwanto, 2005, p. 152). Selain integerasi internal (kecil), integerasi lebih besar terjadi dalam kegiatan yang dilakukan Paguyuban Hindu Jawi, misalnya slametan dan basarah. Pada kedua kegiatan ini kehadiran umat Hindu Bali dan Kaharingan adalah sebuah bentuk integerasi sosial yang lebih luas, bahkan dihadiri oleh tetangga mereka yang berasal dari agama yang berbeda. Latar belakang kelompok etnis, budaya, sosial bersatu dalam persembahyangan basarah. Dengan demikian kegiatan atau acara yang dilaksanakan oleh Paguyuban Hindu Jawi fungsional untuk menciptakan integerasi umat Hindu di Kota Palangka Raya. Dalam konteks ini, O’Dea (1996:27-28) mengemukakan melalui peran serta manusia di dalam ritual agama dan doa, mereka juga melakukan unsur-unsur signifikan yang ada dalam identitasnya. Bahkan dalam menjaga keseimbangan hubungan sosial selalu menggunakan istrumen upacara-upacara sosial (adat) dan keagamaan. Seremoni (upacara) menopang kebutuhan kebutuhan hubunganhubungan sosial yang lebih luas yang digunakan manusia untuk menopang kehidupan mereka (Sy, 2010, p. 60).

\section{Solidaritas Sosial}


Solidaritas menekankan pada kebersamaan dan kerja sama antar individu dengan individu, individu dengan kelompok dan antara kelompok dengan kelompok (Mantra, 1996, $p$. 13). Solidaritas secara psikologis akan merasa memiliki kesamaan dalam satu kesatuan: iman dan kepercayaan. Rasa kesatuan ini akan membina rasa solidaritas dalam kelompok maupun perorangan, bahkan kadang-kadang dapat membina rasa persaudaraan yang kokoh. Pada beberapa agama rasa itu bahkan mengalahkan rasa kebangsaan (Ishomiddin, 2002, p. 55). Fungsi solidaritas sosial sangat nampak dalam aktivitas gotong royong yang dilakukan Paguyuban Hindu Jawi. Gotong royong, baik secara pribadi maupun melibatkan umat. Selain gotong royong, sumbangan juga diberikan kepada anggota yang mengalami musibah, termasuk bencana gempa seperti yang menimpa umat Hindu di Lombok. Makna menyumbang memiliki arti yang luas berdasarkan pemahaman orang Jawa. tentang hal ini Puspo Renan Joyo (wawancara 26 Agustus 2018) mengartikannya secara lebih mendalam seperti penuturannya berikut ini.

"Konsep nyumbang itu, sing iso nyumbang pikiran, pikiran, sing iso nyumbang bondo, yo bondo, sing iso nyumbang tenogo, tenogo. Orang Jawa memahami sumbangan itu tidak sama (ondo usuk) ada yang tinggi rendah. kalo ini disamaratakan itu namanya mengingkari alam".

Pemaknaan solidaritas dalam bentuk gotong royong ataupun sumbangan kepada yang membutuhkan acap menjadi anjuran bahkan bisa menjadi suatu tuntutan dalam berbagai kelompok ataupun komunitas dimasyarakat, dengan alasan untuk saling tolong menolong dan karena solidaritas pula para kelompok dalam masyarakat dapat bersatu. Dalam melakukan kegiatan sosial, seperti gotong royong dan sumbangan Pandu Jawi tetap memegang teguh rasa solidaritas dan gotong royong, sebagai contoh apabila ada kematian, kelahiran dan orang sakit, tetangga-tetangga akan mendatangi yang bersangkutan tersebut sebagai rasa solidaritasnya, atau adanya iuran duka/bencana apabila ada warga yang mengalami kejadian menyedihkan, maka secara otomatis mereka akan memberikan pertolongan.

\section{Penyangga Budaya}

\section{Adaptasi Budaya}

Terdapat hal penting yang dilakukan Paguyuban Hindu Jawi terkait dengan persoalan adaptasi budaya, yaitu melaksanakan basarah. Misalnya kegiatan basarah pribadi yang dilakukan oleh Mujoyono adalah bentuk adaptasi budaya Kaharingan. Melaksanakan basarah menjadi salah satu staregi adaptasi Paguyuban Hindu Jawi berdasarkan kosep desa, kala, dan patra sebagai konstruksi implementasi agama Hindu di Indonesia. Berdasarkan penuturan Mujiyono (wawancara, 2 Oktober 2018) dijelaskan seperti berikut., 
“...Saya telah dua kali selama di Palangka Raya melaksanakan basarah keluarga dirumah. Basarah itu adalah ungakapan rasa syukur yang saya wujudkan setelah katakanlah rezeki lebih yang saya nikmati. Pilihan menggunakan basarah dan bukan selametan ala Jawa adalah berdasarkan konsepsi desa, kala dan patra yang sewajarnya harus kita implementasikan. Bahkan dalam Manawa Dharmasastra ada tambahannya yaitu, iksa dan sakti. Menurut saya salah satu upaya kita mewujudkan konsepsi yang tiga tadi adalah dengan melaksanakan basarah. Dan saya rasa ini menjadi baik untuk kita semua khususnya umat Hindu di Kota Palangka Raya, baik yang Bali, Jawa dan Dayak..."

Alasan pelaksanaan basarah yang dilakukan Mujiyono sebagi implementasi nilai desa, kala dan patra seperti wawancara diatas merupakan fungsi adapatasi. Dalam beradaptasi dengan lingkungannya, seseorang atau sekelompok orang membawa serta norma-norma yang mengendalikan tingkah laku dan peran yang dimainkannya (Daeng, 2000, p. 44). Dalam konteks etnik maupun golongan sosial, melihat, menginterpretasikan dirirnya dengan lingkungan fisik tertentu. Dengan kata lain sejauhmanakah kebudayaan yang dimiliki oleh suatu komunitas tertentu dipakai sebagai suatu strategi adaptasi dalam menghadapi suatu lingkungan biogeofisik tertentu sehingga ia tetap mampu melangsungkan kehidupannya (Poerwanto, 2005, p. 172).

Pengetahuan tentang desa berarti 'ruang'. Kala berarti 'waktu' dan patra berarti 'orang'. Ketiganya menunjuk tiga dimensi dalam melaksanakan ritual. Prinsipnya, ada bagian ritual yang dapat disesuaikan dengan kondisi dan situasi ruang, waktu dan orang. Tapi tetap ada prinsip standar, sesuai dengan pelembagaan ajaran. Ajaran itu sendiri terkena hukum DesaKala-Patra dalam skala yang besar. Pada jamannya, Weda dikembangkan menjadi upanisad. Dan pada jaman upanisad dikembangkan menjadi purana-purana, Manawa Dharmasastra, Darsana, dan demikian seterusnya. Sanatana Dharma atau Dharma abadi menemukan penjelasannya justeru pada keluwesan Desa-Kala-Patra (Palguna, 2011, p. 37). Desa-KalaPatra menunjukkan penerimaan terhadap kenyataan hidup bahwa dalam keseragaman ada keragaman, dalam kesatuan pasti ada perbedaan. Hal ini menggambarkan tentang bentuk komunikasi budaya Bali baik keluar maupun kedalam (Mantra, 1996, p. 14).

\section{Startegi Pewarisan Nilai-Nilai Hindu Jawa}

Fungsi Penyangga budaya lainnya, adalah startegi pewarisan nilai-nilai Hindu Jawa. Hindu Jawa dalam aktivitas keagamaanya sejatinya menekankan pada nilai tattwa dan etika daripada upacara. Walaupun kini tidak dapat diabaikan banyak pula orang Jawa yang mengadopsi sistem upacara dan upakara Hindu yang ada di Bali. Konsekuensinya banyak 
banten Bali hadir dalam upacara-upacara Hindu Jawa, minimal pejati. Tentang hal tersebut dituturkan oleh Mujiyono (wawancara, 3 September 2018) sebagai berikut.

"Kini pejati adalah banten inti selain tumpeng, ayam dan ketupat bagi orang Jawa. Lihat saja ketika orang Jawa ke Pura, pejati adalah jenis upakara yang tidak dapat diabaikan, demikian pula pada upacara slametan, pejati senantiasa hadir didepan tumpeng dan jenis upakara pendukung lainnya. Oleh sebab itu, jenis banten ini merupakan kewajiban bagi orang Jawa. selain pejati, tumpeng, ketupat dan rangkaian buah juga menjadi kewajiban dalam setiap upacara Jawa. Oleh sebab itu cara pembuatannya acapkali melibatkan ibu-ibu. Meski tidak begitu formal, cara-cara pembuatan ini sering dilakuakan sehari atau dua hari sebelum upacara dilakukan. Misalnya Ruwahan, slametan kelahiran anak dan lain-lain. Berbeda dengan Bali jika dalam sebuah upacara jauh-jauh hari telah dipersiapkan".

Strategi pewarisan nilai-nilai Hindu Jawa, salah satunya adalah membuat berbagai sarana upakara, kegiatan ini merupakan bentuk sosialisasi. Lewat proses sosialisasi itu pula norma-norma sosial diwariskan, semisal etika dan tattwa pembuatan tumpeng dan lain sebagainya. Meski dengan pengetahuan yang tidak begitu lengkap sebagaimana di daerah asalnya, namun secara fungsional kegiatan ini mampu memberikan kontribusi penting bagi pelestarian nilai-nilai Hindu Jawa di Kota Palangka Raya.

\section{Penyangga Ekonomi Umat}

Sebagaimana dikemukakan sebelumnya bahwasanya Paguyuban Hindu Jawi tidak semata-mata sebagai wadah berkumpul, berinteraksi dan melakukan berbagai kegiatan sosial keagamaan. Tetapi lebih dari itu paguyuban Hindu Jawi sedikitnya telah berkontribusi ekonomi bagi anggotanya. Seperti keberadaan simpan pinjam bentukan Paguyuban Hindu Jawi bertujuan memberikan bantuan bergulir kepada anggota yang membutuhkan. Respon positif juga datang dari semua anggota, paling tidak kelak jika ingin meminjam uang tidak kepada rentenir dengan bunga setinggi langit, ya minimal mereka (rentenir) membungakan uang itukan rata-rata $10 \%$. Jadi kalo kita punya kas, para anggotakan tidak terjebak utang dengan bunga tinggi.

Selian itu fungsi penyangga ekonomi umat juga sangat nampak dalam berbagai pembinaan yang dilakukannya. Khususnya kegiatan pelatihan fermentasi makanan ternak (babi). Seberapa penting pelatihan fermentasi makanan babi ini, Budi Purnomo (wawancara, 10 Oktober 2018) menuturkan dengan melakukan contoh penyebaran Islam di Indonesia, melalui perdagangan Islam menyebarkan pengaruhnya, oleh sebab itu kita harus dapat membaca itu dengan baik. Artinya berkembang atau mundurnya bahkan hilangnya agama Hindu tergantung dari kekuatan ekonomi umat. Oleh sebab itu untuk memulainya kita ajari umat agar dapat mengembangkan ternaknya dengan cepat dan menekan pengeluaran untuk 
membeli makanan babi, khususnya dedak yang kini mencapai Rp. 3000/kg. Hitung saja jika umat Hindu Kaharaingan memelihara 5 (lima) ekor babi dan bila satu ekor dalam sebulam membutuhkan biaya Rp. 90.000. kalikan 5 (lima) sudah berapa? Jauh lebih hemat jika menggunakan makanan olahan sendiri dengan fermentasi makanan babi yang mampu menekan pengeluaran hampir $50 \%$.

Berdasarkan wawancara dengan Budi Purnomo, respon yang diberikan oleh umat kaharingan terhadap bentuk kegiatan pelatihan fermentasi makanan ternak sangat positif. Meskipun hasil dari pelatihan tersebut belum menampakkan wujud yang signifikan terhadap pertumbuhan babi, tetapi secara esfesiensi pelatihan tersebut mampu meringankan beban umat yang berlatar belakang petani maupun peternak dengan modal yang minim.

Pelatihan ini adalah untuk memperkuat ekonomi umat Hindu, khususnya di pedesaan. Secara realitas kegiatan pelatihan ini memberikan alternatif bagi umat Hindu Kaharingan untuk meningkatkan pendapatannya sekaligus dapat menekan biaya pengeluaran pemeliharaan babi yang selama ini dianggap terlalu tinggi. Akibatnya daya tarik untuk berternak berkurang, namun dengan adanya model pelatihan sederhana seperti yang dilakukan oleh Budi Purnomo setidaknya terdapat harapan baru terhadap kemajuan ekonomi mereka.

\section{Simpulan}

Eksistensi Paguyuban Hindu Jawi di Kota Palangka Raya ditopang dari berbagai aspek kegiatan yang dilakukan baik secara eksternal maupun internal. Kegiatan eksternal seperti pemberdayaan ekonomi umat melalui pelatihan fermentasi makanan ternak mampu menyentuh langsung umat Hindu Kaharingan yang memang benar-benar membutuhkan (tepat sasaran). Selain itu, gotong-royong sebagai kegiatan eksternal telah memberikan dampak signifikan terhadap eksistensi Paguyuban Hindu Jawi, sebab kehadiran mereka dalam kegiatan gotongroyong menunjukkan eksistensi sekaligus kontribusi mereka baik tenaga maupun pikiran. Sedangkan untuk kegiatan internal, eksistensi Paguyuban Hindu Jawi ditopang oleh berbagai bentuk ritus slametan dan basarah. Ritus salmetan adalah bentuk strategi pewarisan dan upaya pelestarian nilai-nilai Hindu Jawa. sedangkan basarah adalah bentuk adaptasi Paguyuban Hindu Jawi dengan tradisi budaya dan agama Hindu Kaharingan. 


\section{Daftar Pustaka}

Achmad, S. W. (2018). Etika Jawa: Pedoman Luhur dan prinsip Hindup orang Jawa. Yogyakarta: Araska Publisher.

Armadiansyah. (2011). Eksistensi Damang Sebagai Hakim Perdamaian Adat Pada Masyarakat Suku Dayak di Palangka Raya. Denpasar: Program Pasca Sarjana Universitas Udayana. BPS. (2017). Kota Palangka Raya dalam Angka (Palangka Raya Municipality in Figures). Kota Palangka Raya: Badan Pusat Statistik.

Daeng, H. J. (2000). Manusia, Kebudayaan dan Lingkungan: Tinjauan Antropologi. Yogyakarta: Pustaka Pelajar Offset.

Danandjaja, J. 1. (1975). Kebudayaan Kalimantan Tengah . In Koentjaraningrat, Kebudyaaan Indonesia. Jakarta: PT. Pembangunan.

Efendi, B. (1997). Masyarakat Agama dan Tantangan Globalisasi; Mempertimbangkan Konsep Deprivatisasi Agama. Jurnal ulumul Qur'an no 3/VII , hlm.43.

Endraswara, S. (2016). Mistik Kejawen: Sinkretisme, Simbolisme dan Sufisme dalam Budaya Spiritual Jawa. Yogyakarta: Narasi.

Geertz, C. (1983). The Religion of Java. London The Free Press. (Abangan, Santri, Priyayai dalam Masyarakat Jawa). Hak Penerbitan bahasa Indonesia pada Yayasan Ilmu-Ilmu Sosial kerjasama Yayasan Ilmu-Ilmu Sosial. Jakarta: PT Dunia Pustaka Jaya.

Geria, I. W. (2009). Tranformasi Kebudayaan Bali Abas XXI. Denpasar: Dinas Kebudayaan Bali.

Ghindwani, H. D. (2006). Hindu Agama Universal. Jakarta: Media Hindu.

Hartati, S. (2015). Data Umat Hindu Se-Kalimantan Tengah, Disampaikan dalam Rapat Koordinasi lembaga keagamaan Hindu Kantor Wilayah kemenag Provinsi Kalimantan Tengah Tahun 2015, Palangka Raya, 27 s.d. 29 Juli 2015. Palangka Raya.

Hindu., D. B. (2009). Pedoman Pelaksanaan Manusa Yadnya di Jawa. Jakarta: Departemen Agam Direktorat Jenderal Bimbingan Masyarakat Hindu.

Ishomiddin. (2002). Pengantar Sosiologi Agama. Jakarta: PT. Ghalia Indonesia dengan UMM Press.

Lingu, A. L. (2001). Menjawab Tantangan Terjadinya Kerusuhan di Kalimantan Tengah. Palangka Raya: Pusat Penelitian Kebudayaan Dayak Lembaga Penelitian Universitas Palangka Raya dengan Majelis Adat Dayak Provinsi Kalimantan Tengah.

Mantra, I. B. (1996). Bali Masalah Sosial Budaya dan Modernisas. Denpasar: PT. Upada Sastra.

Mujiyono. (2018, September Senin, 3). Historitas Paguyuban Hindu Jawi.

O’Dea, T. F. (1996). Sosiologi Agama suatu Pengantar Awa. Jakarta: PT RajaGrafindo Persada.

Palguna, I. D. (2011). Leksikon Hindu. Jakarta: CV. Zalfindo Perdana.

Penyusun, T. (2003). Bahan Ajar Acara Agama Hindu Kaharingan. Palangka Raya: STAHN TP.

Penyusun, T. (2005). Kamus Besar Bahasa Indonesa Edisi III. Jakarta: Balai Pustaka.

Poerwanto, H. (2005). Kebudayaan dan Lingkungan dalam Perspektif Antropologi. Yogyakarta: Pustaka Pelajar Offset.

Purwadi. (2007). Filsafat Jawa dan Kearifan Lokal. Yogyakarta: Panji Pustaka.

Raya, B. P. (2017). Kota Palangka Raya dalam Angka (Palangka Raya Municipality in Figures). Palangka Raya: Badan Pusat Statistik.

Samovar, Larry A. Porter, Ricard E. McDaniel, Edwin R. . (2010). Komunikasi Lintas Budaya (Comminication Between Culltures) penerj. Indri Margaretha Sidabalok. Jakarta: Salemba Humanika. 
Sartini, N. W. (2015). Kajian Dharma Wacana Diaspora Hindu-Bali di Jawa Timur. Jurnal Kajian Bali Volume 05, Nomor 02, Oktober., 222.

Sugiyarto, W. (2016). Eksistensi Agama Hindu Kaharingan di Kalimantan Tengah. Harmoni: Multikultural dan Multireligus Vol 15, 112.

Suripto, A. (2006). Nilai-Nilai Hindu dalam Budaya Jawa: Serpihan Tertinggal. Jakarta: Media Hindu.

Sutrisno, N. (2009). Rekonstruksi Identitas Hindu di Jawa. In PHDI Setengah Abad sebuah Retropeksi Bhineneka Tunggal Ika Tan Hana Dharma Mangrwa (p. 196). Denpasar.

Sy, P. (2010). Politik Pencitraan. Jakarta: Gaung Persada.

Takwin, B. (2009). Filsafat Timur, Sebuah Pengantar ke Pemikiran Pemikiran Timur. Yogyakarta \& Bandung:: Jalasutra.

Titib, I. M. (1998). Veda Sabda Suci Pedoman Praktis Kehidupan. Surabaya: Paramita.

Widyaningrum, L. (2017). Tradisi Adat Jawa dalam Menyambut Kelahiran Bayi (Studi Tentang Pelaksanaan Tradisi Jagongan Pada Sepasaran Bayi) di Desa Harapan Harapan Jaya Kecamatan Pangkalan Kuras Kabupaten Pelalawan. JOM FISIP Vol. 4 No. 2 , 5. 